\title{
OPEN High prevalence of undiagnosed comorbidities among adolescents with obesity
}

Karen S. W. Leong ${ }^{1,2}$, Thilini N. Jayasinghe ${ }^{1}$, Brooke C. Wilson ${ }^{1}{ }^{1}$, José G. B. Derraik ${ }^{1,2,3,4}$, Benjamin B. Albert $\mathbb{1}^{1,2}$, Valentina Chiavaroli@1,5, Darren M. Svirskis $\mathbb{1}^{6}$, Kathryn L. Beck ${ }^{7}$, Cathryn A. Conlon $\mathbb{1}^{7}$, Yannan Jiang ${ }^{8}{ }^{8}$, William Schierding ${ }^{1}{ }^{1}$, Tommi Vatanen ${ }^{1}{ }^{1,9}$, David J. Holland ${ }^{10}$, Justin M. O'Sullivan ${ }^{1,2,11 \bowtie ~ \& ~ W a y n e ~ S . ~ C u t f i e l d ~}{ }^{11,2,3,11 \bowtie}$

Metabolic diseases are increasing among adolescents with obesity. Although the reported prevalence of metabolic syndrome is approximately $30 \%$ worldwide, its prevalence is largely unknown among New Zealand adolescents. Therefore, we assessed the health of adolescents with obesity (BMI $\geq 30 \mathrm{~kg} /$ $\mathrm{m}^{2}$ ) enrolled in a randomised clinical trial (Gut Bugs Trial), to identify the prevalence of undiagnosed comorbidities. Assessments included anthropometry, 24-h ambulatory blood pressure monitoring, and insulin sensitivity. We report on baseline data (pre-randomisation) on 87 participants (1418 years; $59 \%$ females), with mean BMI $36.9 \pm 5.3 \mathrm{~kg} / \mathrm{m}^{2}$ (BMI SDS $3.33 \pm 0.79$ ). Approximately $40 \%$ of participants had undiagnosed metabolic syndrome, which was twice as common among males. Half $(53 \%)$ had pre-diabetes and $92 \%$ a reduction in insulin sensitivity. Moreover, $31 \%$ had prehypertension/hypertension, $69 \%$ dyslipidaemia, and $25 \%$ abnormal liver function. Participants with class III obesity had a greater risk of metabolic syndrome than those with classes I/II [relative risk 1.99 $(95 \% \mathrm{Cl} 1.19,3.34)]$. Risks for pre-hypertension/hypertension and inflammation were also greater among those with class III obesity. We identified a high prevalence of undiagnosed comorbidities among adolescents with obesity in New Zealand. As adolescent obesity tracks into adulthood, early interventions are needed to prevent progression to overt cardiometabolic diseases.

With over 120 million affected children and adolescents worldwide, paediatric obesity has become one of the largest health concerns of the modern world ${ }^{1}$. In 2016, the World Health Organization (WHO) estimated that, globally, the prevalence of paediatric overweight and obesity was $18 \%{ }^{2}$. In New Zealand, an even higher rate was reported for the same year, whereby nearly $40 \%$ had overweight or obesity (> $16 \%$ with obesity) ${ }^{3}$. In $2019,22 \%$ of New Zealand adolescents were overweight while $12 \%$ had obesity ${ }^{4}$, which is higher than in many parts of the world such as Australia (combined rate of overweight/obesity is $25 \%)^{5}$, Denmark $(22 \%)^{6}$, and China $(26 \%)^{7}$ but lower than the US $(40 \%)^{8}$. While the prevalence of paediatric obesity seems to have plateaued in many countries ${ }^{9}$ as in New Zealand ${ }^{10}$, the prevalence of adolescents with obesity remains high in New Zealand, particularly among Māori (New Zealand's indigenous people) and Pacific adolescents, and those from areas of greater socioeconomic deprivation $^{4,11}$. Of note, within a 5-year period from 2007 to 2012, there was a rapid increase in the prevalence of Pacific adolescents with obesity (from $27 \%$ to $34 \%$ ) and severe obesity ( $9 \%$ to $14 \%)^{11}$.

Adolescence is a period of accelerated growth characterised by rapid physiological, hormonal, and developmental changes, with marked alterations in body composition and weight gain ${ }^{12}$. There are changes in the hormonal regulation of appetite and satiety in both sexes, as well as increases in adiposity and changes in fat distribution among females, which contribute to a tendency to gain weight in adolescence ${ }^{12,13}$. For some adolescents, the

\footnotetext{
${ }^{1}$ Liggins Institute, University of Auckland, Auckland, New Zealand. ${ }^{2}$ A Better Start-National Science Challenge, Auckland, New Zealand. ${ }^{3}$ Department of Endocrinology, Children's Hospital, Zhejiang University School of Medicine, Hangzhou, China. 'Department of Women's and Children's Health, Uppsala University, Uppsala, Sweden. ${ }^{5}$ Neonatal Intensive Care Unit, Pescara Public Hospital, Pescara, Italy. ${ }^{6}$ School of Pharmacy, Faculty of Medical and Health Sciences, University of Auckland, Auckland, New Zealand. ${ }^{7}$ School of Sport, Exercise and Nutrition, College of Health, Massey University, Auckland, New Zealand. ${ }^{8}$ Department of Statistics, University of Auckland, Auckland, New Zealand. ${ }^{9}$ Broad Institute of MIT and Harvard, Cambridge, MA, USA. ${ }^{10}$ Department of Infectious Diseases, Counties Manukau District Health Board, Auckland, New Zealand. ${ }^{11}$ These authors contributed equally: Justin M. O'Sullivan and Wayne S. Cutfield. ${ }^{凶}$ email: justin.osullivan@auckland.ac.nz; w.cutfield@ auckland.ac.nz
} 
normal changes observed in puberty can be magnified, leading to greater weight gain and metabolic dysfunction, including persistence of insulin resistance ${ }^{14}$. As $90 \%$ of adolescents with obesity continue to have obesity as adults ${ }^{15}$, early intervention is crucial.

Consistent with the rise in obesity, cardiometabolic comorbidities such as metabolic syndrome and type 2 diabetes mellitus (T2DM) are increasing in children and adolescents ${ }^{16}$. Increasing body mass index (BMI) is associated with an increased risk of metabolic syndrome ${ }^{17}$, which includes increased abdominal obesity, hypertension, impaired fasting glycaemia, dyslipidaemia, and is associated with insulin resistance ${ }^{16}$. The prevalence of metabolic syndrome among adolescents with obesity has been reported to be as high as $60 \%{ }^{18}$, and it is associated with the development of T2DM ${ }^{19}$, cardiovascular disease ${ }^{20}$, and a two-fold increase in the risk of coronary artery disease and stroke, and a 1.5-fold increase in the risk of all-cause mortality ${ }^{21}$. In the US, a national cross-sectional study reported that T2DM is increasingly diagnosed among adolescents and accounted for $40 \%$ of adolescent diabetes, with more than a third of T2DM cases undiagnosed prior to the study ${ }^{22}$. In New Zealand, the number of children with T2DM is increasing at approximately $5 \%$ per year, and this disease disproportionally affects highrisk ethnic groups (Māori and Pacific) ${ }^{23}$. Apart from serious cardiometabolic complications, paediatric obesity has been associated with increased mortality even in early adulthood ${ }^{24}$. This is likely due to increased systemic inflammation, insulin resistance, impaired cardiovascular function, and the development of non-alcoholic fatty liver disease $e^{25,26}$. Moreover, many of these children face bullying ${ }^{27}$ and social isolation ${ }^{28}$, as well as increased rates of depression ${ }^{29}$, suicide and self-harm ${ }^{24}$.

Overall, there are limited data on the prevalence of obesity-related comorbidities among adolescents with obesity in New Zealand ${ }^{30,31}$. Due to the numerous complications associated with obesity, early identification particularly in high-risk populations is necessary so that targeted interventions can be implemented. Therefore, we aimed to assess the metabolic health of a group of adolescents with obesity enrolled in a clinical trial and identify the prevalence of undiagnosed metabolic syndrome and other obesity-related cardiometabolic comorbidities.

\section{Methods}

Ethics. This study reported on baseline data (pre-randomisation) from a randomised placebo-controlled trial (Gut Bugs Trial) to evaluate the effectiveness of faecal microbiome transfer for treatment of adolescent obesity in Auckland, New Zealand ${ }^{32}$. The trial was registered with the Australian New Zealand Clinical Trials Registry (ACTRN12615001351505); ethics approval was granted by the Northern A Health and Disability Ethics Committee (16/NTA/172). Participants provided verbal and written informed consents. All procedures in this study were conducted according to the ethical principles and guidelines laid down in the Declaration of Helsinki ${ }^{33}$.

Recruitment. Participants were recruited from social media through Facebook advertisements between 2017-2018. All were post-pubertal, aged $14-18$ years, with $B M I \geq 30 \mathrm{~kg} / \mathrm{m}^{2}$, who were not diagnosed with diabetes or chronic diseases that could affect weight or metabolism ${ }^{32}$.

Clinical assessments. Clinical assessments included medical and physical examinations previously described in the trial's protocol ${ }^{32}$, and briefly summarised here.

Height, weight, and waist and hip circumferences were measured ${ }^{32}$. BMI values were converted into standard deviation score (SDS) using WHO standards ${ }^{34}$. For comparison within our study population, BMI was stratified using the adult criteria for obesity: Class I $\left(\mathrm{BMI} \geq 30\right.$ but $\left.<35 \mathrm{~kg} / \mathrm{m}^{2}\right)$; Class II $\left(\geq 35\right.$ but $\left.<40 \mathrm{~kg} / \mathrm{m}^{2}\right)$; and Class III $\left(\geq 40 \mathrm{~kg} / \mathrm{m}^{2}\right)^{35}$. Body composition was assessed using whole-body dual-energy X-ray absorptiometry (DXA; Lunar Prodigy and Lunar iDXA; GE Medical Systems, Chicago, Illinois, USA).

Clinic resting systolic and diastolic blood pressures (BP) were measured using an automated BP monitor (Richampion N; Riester, Jungingen, Germany). 24-h ambulatory BP monitoring (24hABPM) was performed using an oscillometric device (Spacelabs OnTrak; Spacelabs Medical Inc, Redmond, Washington, USA).

Participants underwent a 75-g oral glucose tolerance test (OGTT) ${ }^{32}$. Insulin sensitivity was assessed by homeostatic model assessment of insulin resistance (HOMA-IR) ${ }^{36}$ and Matsuda index ${ }^{37}$, as previously described ${ }^{32}$. Other key markers of glucose metabolism measured were fasting insulin and fasting glucose, 2-h glucose, and glycated haemoglobin (HbAlc). From fasting blood samples, uric acid, high-sensitivity C-reactive protein (hsCRP), lipid profile, and liver function were measured ${ }^{32}$.

Health outcomes in this study were cardiometabolic comorbidities as defined in Table 1.

Assays. Insulin levels were measured by electrochemiluminescence immunoassay (ECLIA) on the Roche Cobas e411 analyser (Roche, Basel, Switzerland) with a coefficient of variation (CV) of 1.2\%. Glucose, HbA1c, uric acid, hsCRP, lipid profile, and liver function were measured on the Roche/Hitachi Cobas e311 (Roche) with CVs $4.1-6.8 \%$.

Data analyses. Data were analysed using SPSS v25 (IBM Corp, Armonk, NY, USA) and SAS v9.4 (SAS Institute, Cary, NC, USA). Baseline data were summarised as mean \pm standard deviation (SD), median [quartile 1, quartile 3], or n (\%), as appropriate. Differences in prevalence between obesity classes and sexes were examined with Chi-square tests or Fisher's exact tests, as appropriate. The likelihood of given comorbidities in participants with class III obesity was assessed with generalized linear regression models, using PROC GENMOD (SAS), adjusting for sex, and relative risk estimation by Poisson regression with robust error variance, and a log $\operatorname{link}^{38}$. The results were reported as relative risks (RR) with respective $95 \%$ confidence intervals (95\% CI). Statistical tests were two-tailed, with significance levels maintained at $\mathrm{p}<0.05$. 


\begin{tabular}{|c|c|c|c|c|}
\hline \multicolumn{2}{|l|}{ Assessments } & \multirow{4}{*}{\begin{tabular}{|l} 
Comorbidities \\
Elevated waist circumference
\end{tabular}} & \multirow{2}{*}{\begin{tabular}{|l|} 
Thresholds for abnormal results \\
$\begin{array}{l}14 \text { years: } \geq 90 \text { th percentile }(\geq 79.9 \mathrm{~cm} \text { for } \\
\text { males; } \geq 77 \mathrm{~cm} \text { for females })\end{array}$
\end{tabular}} & \multirow{4}{*}{$\begin{array}{l}\text { References } \\
\text { Zimmet et al. } 2007^{16} \text {; Eisenmann et al. } 2005^{63}\end{array}$} \\
\hline \multirow{3}{*}{ Waist circumference } & & & & \\
\hline & & & $\begin{array}{l}15 \text { years: } \geq 90 \text { th percentile }(\geq 81.7 \mathrm{~cm} \text { for } \\
\text { males; } \geq 78.4 \mathrm{~cm} \text { for females })\end{array}$ & \\
\hline & & & $\geq 16$ years: $\geq 94 \mathrm{~cm}$ for males and $\geq 80 \mathrm{~cm}$ for females & \\
\hline \multirow{8}{*}{ Glucose homeostasis } & & Elevated fasting glucose & Fasting blood glucose $\geq 5.6 \mathrm{mmol} / \mathrm{L}$ & \multirow{8}{*}{$\begin{array}{l}\text { American Diabetes Association } 2018^{53} \text {; Frithioff } \\
\text { Bøjsøe et al. } 2019^{64}\end{array}$} \\
\hline & & Elevated 2-h glucose (OGTT) & 2-h blood glucose $\geq 7.8 \mathrm{mmol} / \mathrm{L}$ & \\
\hline & & \multirow{2}{*}{ Elevated HbA1c } & $\mathrm{HbAlc} \geq 39 \mathrm{mmol} / \mathrm{mol}$ & \\
\hline & & & HbAlc $\geq 5.7 \%$ & \\
\hline & & \multirow{2}{*}{ Elevated fasting insulin } & $\begin{array}{l}<15 \text { years: }>11.4 \mu \mathrm{U} / \mathrm{mL} \text { for males and }>14.0 \mu \mathrm{U} / \\
\mathrm{mL} \text { for females }\end{array}$ & \\
\hline & & & $\begin{array}{l}\geq 15 \text { years: }>11.4 \mu \mathrm{U} / \mathrm{mL} \text { for males and }>12.9 \mu \mathrm{U} / \\
\mathrm{mL} \text { for females }\end{array}$ & \\
\hline & & Pre-diabetes & $\begin{array}{l}\text { Fasting glucose } \geq 5.6 \mathrm{but}<7.0 \mathrm{mmol} / \mathrm{L} ; 2 \text {-h } \\
\text { glucose } \geq 7.8 \mathrm{but}<11.1 \mathrm{mmol} / \mathrm{L} ; \mathrm{HbAlc} \geq 39 \\
\text { but }<48 \mathrm{mmol} / \mathrm{mol}\end{array}$ & \\
\hline & & Diabetes & $\begin{array}{l}\text { Fasting glucose } \geq 7.0 \mathrm{mmol} / \mathrm{L} ; 2 \text {-h glu- } \\
\text { cose } \geq 11.1 \mathrm{mmol} / \mathrm{mol} ; \mathrm{HbA} 1 \mathrm{c} \geq 48 \mathrm{mmol} / \mathrm{mol}\end{array}$ & \\
\hline \multirow{2}{*}{ Insulin resistance ${ }^{\mathrm{a}}$} & & High HOMA-IR & HOMA_IR $>3.16$ & Keskin et al. $2005^{39}$ \\
\hline & & Low Matsuda index & Matsuda index $\leq 2.5$ & Kernan et al. $2003^{40}$ \\
\hline \multirow{7}{*}{ Blood pressure } & \multirow{4}{*}{ Clinic BP } & \multirow{2}{*}{ Pre-hypertension } & $\begin{array}{l}<16 \text { years: SBP and/or DBP } \geq 90 \text { th but }<95 \text { th percen- } \\
\text { tile for age and sex }\end{array}$ & \multirow{7}{*}{ Lurbe et al. $2016^{62}$} \\
\hline & & & $\begin{array}{l}\geq 16 \text { years: } \mathrm{SBP} \geq 130 \text { but }<140 \mathrm{mmHg} \text { and/or } \\
\mathrm{DBP} \geq 85 \text { but }<90 \mathrm{mmHg}\end{array}$ & \\
\hline & & Hypertension & $\begin{array}{l}<16 \text { years: SBP and/or DBP } \geq 95 \text { th percentile for age } \\
\text { and sex }\end{array}$ & \\
\hline & & & $\geq 16$ years: $\mathrm{SBP}$ and/or $\mathrm{DBP} \geq 140 / 90 \mathrm{mmHg}$ & \\
\hline & \multirow{3}{*}{ 24hABPM } & Pre-hypertension & $\begin{array}{l}\text { SBP and/or DBP } \geq 90 \text { th but }<95 \text { th percentile for age } \\
\text { and sex }\end{array}$ & \\
\hline & & Hypertension & $\begin{array}{l}\text { SPB and/or DBP } \geq 95 \text { th percentile for sex, age, and } \\
\text { height, unless BP is equal to or higher than adult } \\
\text { criteria thresholds (i.e. mean } 24 \mathrm{hr} 130 / 80 \mathrm{mmHg} \text {; } \\
\text { awake } 135 / 85 \mathrm{mmHg} \text {; and sleep } 125 / 75 \mathrm{mmHg} \text { ) }\end{array}$ & \\
\hline & & Non-dippers & Nocturnal drop in SBP and/or DBP $\leq 10 \%$ & \\
\hline \multirow{6}{*}{ Lipid profile } & & & $<16$ years: $<1.03 \mathrm{mmol} / \mathrm{L}$ & \multirow[b]{2}{*}{ Zimmet et al. $2007^{16}$} \\
\hline & & Low HDL & $\begin{array}{l}\geq 16 \text { years: } \text { males }<1.03 \mathrm{mmol} / \mathrm{L} \\
\text { females }<1.29 \mathrm{mmol} / \mathrm{L}\end{array}$ & \\
\hline & & High LDL & $>2.6 \mathrm{mmol} / \mathrm{L}$ & NCEP $2001^{65}$ \\
\hline & & High triglycerides & $\geq 1.7 \mathrm{mmol} / \mathrm{L}$ & Zimmet et al. $2007^{16}$ \\
\hline & & High total cholesterol & $>5.2 \mathrm{mmol} / \mathrm{L}$ & \multirow[b]{2}{*}{ European Atherosclerosis Society $1987^{66}$} \\
\hline & & Dyslipidaemia & $\begin{array}{l}\text { Low HDL or high LDL or high triglycerides or high } \\
\text { total cholesterol }\end{array}$ & \\
\hline \multirow{3}{*}{ Inflammatory markers } & Uric acid & Hyperuricaemia & Males $\geq 417 \mu \mathrm{mol} / \mathrm{L}$; females $\geq 340 \mu \mathrm{mol} / \mathrm{L}$ & Thefeld et al. $1973^{67}$ \\
\hline & \multirow{2}{*}{ hsCRP } & \multirow{2}{*}{ Elevated hsCRP } & $<16$ years: $>2.8 \mathrm{mg} / \mathrm{L}$ & Schlebusch et al. $2002^{68}$ \\
\hline & & & $\geq 16$ years $\geq 5.0 \mathrm{mg} / \mathrm{L}$ & Dati et al. $1996^{69}$ \\
\hline \multirow{4}{*}{ Liver function } & & Elevated ALT & Males > $41 \mathrm{U} / \mathrm{L}$; females $>33 \mathrm{U} / \mathrm{L}$ & Klein et al. $1994^{70}$ \\
\hline & & Elevated AST & Males $>40 \mathrm{U} / \mathrm{L}$, females $>32 \mathrm{U} / \mathrm{L}$ & Thefeld et al. $1974^{71}$ \\
\hline & & Elevated GGT & Males $\geq 60 \mathrm{U} / \mathrm{L}$, females $\geq 40 \mathrm{U} / \mathrm{L}$ & \multirow{2}{*}{ Thomas et al. $2005^{72}$} \\
\hline & & Abnormal liver function & Elevated ALT or elevated AST or elevated GGT & \\
\hline \multirow[b]{2}{*}{ Metabolic health } & & \multirow[b]{2}{*}{ Metabolic syndrome } & $\begin{array}{l}\geq 10 \text { but }<16 \text { years: } \\
\text { Waist circumference } \geq 90 \text { th percentile (or adult cut- } \\
\text { off if the latter is lower); AND any } 2 \text { of the following } \\
4 \text { criteria: } \\
\text { 1. triglycerides } \geq 1.7 \mathrm{mmol} / \mathrm{L} \\
\text { 2. } \mathrm{HDL}<1.03 \mathrm{mmol} / \mathrm{L} \\
3 . \mathrm{SBP} \geq 130 \text { and } / \text { or } \mathrm{DBP} \geq 85 \mathrm{mmHg} \\
4 \text {. Fasting glucose } \geq 5.6 \mathrm{mmol} / \mathrm{L} \text { and } / \text { or previously } \\
\text { diagnosed type } 2 \text { diabetes }\end{array}$ & \multirow[b]{2}{*}{ Zimmet et al. $2007^{16}$} \\
\hline & & & $\begin{array}{l}\geq 16 \text { years: } \\
\text { Waist circumference } \geq 94 \mathrm{~cm} \text { for males and } \geq 80 \mathrm{~cm} \\
\text { for females; AND any } 2 \text { of the following } 4 \text { criteria: } \\
1 \text {. triglycerides } \geq 1.7 \mathrm{mmol} / \mathrm{L} \\
2 . \mathrm{HDL}<1.03 \mathrm{mmol} / \mathrm{L} \text { in males and }<1.29 \mathrm{mmol} / \mathrm{L} \\
\text { in females; or specific treatment for these lipid } \\
\text { abnormalities } \\
3 \text {. SBP } \geq 130 \mathrm{mmHg} \text { and } / \text { or } \mathrm{DBP} \geq 85 \mathrm{mmHg} \text {, or } \\
\text { treatment for previously diagnosed hypertension } \\
\text { 4. Fasting glucose } \geq 5.6 \mathrm{mmol} / \mathrm{L} \text { and } / \text { or previously } \\
\text { diagnosed type } 2 \text { diabetes }\end{array}$ & \\
\hline
\end{tabular}




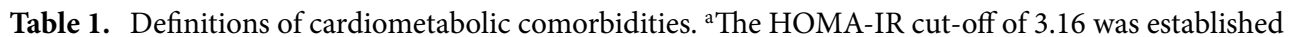
from a group of adolescents ${ }^{39}$ and the Matsuda index cut-off of 2.5 was established from a group of healthy adults $^{40}$. 24hABPM 24-h ambulatory blood pressure monitoring, $A L T$ alanine transaminase, $A S T$ aspartate transaminase, $B P$ blood pressure, $D B P$ diastolic blood pressure, GGT gamma-glutamyl transferase, $h s C R P$ high-sensitivity C-reactive protein, $H b A 1 c$ haemoglobin A1c, $H D L$ high-density lipoprotein cholesterol, $H O M A-I R$ homeostatic model assessment of insulin resistance, $L D L$ low-density lipoprotein cholesterol, $S B P$ systolic blood pressure.

\section{Results}

Participants. 565 participants responded to advertisements; 328 (58\%) were not eligible and 150 (27\%) declined to participate. Thus, 87 participants (59\% females) were recruited at a median age of 17.6 years (Table 2). $44 \%$ of our cohort were Māori or Pacific, and nearly $30 \%$ were from the most-deprived quintile of socioeconomic deprivation (Table 2). Their mean BMI was $36.9 \mathrm{~kg} / \mathrm{m}^{2}$ (range 31.6-42.3 kg/m²), with mean BMI SDS 3.33 (range $2.10-6.38$ ); 33\%, 38\%, and $29 \%$ of participants were classified as obesity class I, II, and III, respectively (Table 2). Mean total body fat was approximately $50 \%$ (Table 2 ).

Comorbidities. There was a high prevalence of undiagnosed comorbidities (Table 3). Notably, one in three participants (36\%) had undiagnosed metabolic syndrome (Table 3 ), with this condition twice as common among males ( $50 \%$ vs $26 \%$; $=0.018)$.

In addition, $13 \%$ of participants had pre-hypertension and $8 \%$ had hypertension from clinic BP. From $24 \mathrm{hABPM}$ data, $17 \%$ were pre-hypertensive and $14 \%$ hypertensive with nocturnal pre-hypertension recorded in $18 \%$ and nocturnal hypertension in $10 \%$ of participants (Table 3 ).

Pre-diabetes was common, affecting approximately half of participants (52\%): $29 \%$ females and $83 \%$ males $(\mathrm{p}<0.0001)$. Fasting insulin was elevated in $94 \%$ of participants including all the males (Table 3$)$. Most participants displayed a reduction in insulin sensitivity, as $92 \%$ had a high HOMA-IR when compared to a cohort of adolescents $^{39}$, and $87 \%$ had a low Matsuda index when compared to healthy adults ${ }^{40}$ (Table 4 ).

Dyslipidaemia and abnormal liver function affected $74 \%$ and $25 \%$ of participants respectively (Table 3 ). Inflammatory markers were elevated, with $61 \%$ having hyperuricaemia and $28 \%$ with elevated hsCRP (Table 3 ).

BMI classes. There were marked differences in the prevalence of cardiometabolic comorbidities between obesity classes (Table 4). The risk of metabolic syndrome increased among those with class III obesity compared to those with a lesser degree of obesity [RR 1.99 (95\% CI 1.19, 3.34); $\mathrm{p}=0.0091$ ] (Table 4). The prevalence of BP abnormalities was markedly higher in participants with class III obesity, with the relative risks of prehypertension/hypertension and loss of the nocturnal dipping BP status more than 3 times greater in this group (Table 4). A higher BMI was associated with an increased likelihood of inflammation, with the relative risk of hyperuricaemia and elevated hsCRP being 1.4 and 2.1 times greater in participants with class III obesity, respectively (Table 4).

\section{Discussion}

We identified a high prevalence of undiagnosed comorbidities amongst our cohort of adolescents with obesity. Notably, more than a third were diagnosed with metabolic syndrome, which was twice as common in males than in females. More than half (52\%) of our cohort had pre-diabetes and more than $90 \%$ had fasting hyperinsulinaemia, with higher rates of these complications in males. In addition, almost all had a reduction in insulin sensitivity. Moreover, increased levels of adiposity were associated with a higher risk of metabolic syndrome, hypertension, and inflammation. The presence of these adverse cardiometabolic outcomes at a relatively young age is alarming, and along with published data documenting the tracking of weight-related comorbidities from childhood into adulthood ${ }^{41}$, further reaffirms that obesity in adolescence is far from a benign condition.

A description of comorbidities among 239 children and adolescents with obesity in New Zealand was provided by Anderson et al. in $2016^{30}$. In that study, 1 in 10 had elevated blood pressure, 1 in 4 had increased inflammation, and nearly half had dyslipidaemia and abnormal liver function ${ }^{30}$. While their reported prevalence of obesity-related comorbidities were relatively high, they were lower than those observed in the present study ${ }^{30}$, probably because their study population was younger (mean age 10.7 vs 17.2 years in our study), leaner (mean BMI 3.09 vs 3.33 SDS), and had a different ethnic make-up with a much lower representation from those of Pacific descent (3\% vs $23 \%$ ) than ours.

Worldwide, the reported prevalence of metabolic syndrome among children and adolescents with obesity varied between 10 to $66 \%{ }^{18,31,42-50}$. In New Zealand, Grant et al. reported a lower rate of metabolic syndrome among 29 Pacific adolescents with obesity aged $15-18$ years ${ }^{31}-21 \%$ vs $36 \%$ in our study. In comparison, reported rates of metabolic syndrome in adolescents with obesity vary widely across the world: $15 \%$ to $50 \%$ in the US ${ }^{18,50}$, $23 \%$ to $60 \%$ in Latin America ${ }^{18,43,46,49}, 12 \%$ to $42 \%$ in Asia $^{18}$, and $14 \%$ to $44 \%$ in Europe ${ }^{18,44,45,47}$. The marked differences in prevalence among these studies could be attributed to variations in age distribution and ethnic composition of the respective study populations, as well as the definitions of metabolic syndrome used. Nonetheless, the findings from two systematic reviews clearly show increasing BMI as an important risk factor associated with the development of metabolic syndrome ${ }^{18,42}$, with this relationship also shown to occur at the upper end of the BMI spectrum by our stratified analyses. 


\begin{tabular}{|c|c|c|c|}
\hline & All & Females & Males \\
\hline $\mathrm{N}$ & $87(100 \%)$ & $51(59 \%)$ & $36(41 \%)$ \\
\hline Age (years) & $17.6[16.2,18.3]$ & $17.7[16.2,18.3]$ & $16.9[15.9,18.2]$ \\
\hline \multicolumn{4}{|l|}{ Ethnicity } \\
\hline New Zealand European & $43(49 \%)$ & $22(43 \%)$ & $21(58 \%)$ \\
\hline Māori & $18(21 \%)$ & $12(24 \%)$ & $6(17 \%)$ \\
\hline Pacific & $20(23 \%)$ & $13(26 \%)$ & $7(19 \%)$ \\
\hline Asian & $6(7 \%)$ & $4(8 \%)$ & $2(6 \%)$ \\
\hline \multicolumn{4}{|l|}{ Any current drug use } \\
\hline Tobacco smoking & $8(9 \%)$ & $3(6 \%)$ & $5(14 \%)$ \\
\hline Alcohol & $34(39 \%)$ & $25(49 \%)$ & $9(25 \%)$ \\
\hline \multicolumn{4}{|l|}{ Socioeconomic deprivation ${ }^{\mathrm{b}}$} \\
\hline Quintile 1 (least deprived) & $6(7 \%)$ & $3(6 \%)$ & $3(8 \%)$ \\
\hline Quintile 2 & $20(23 \%)$ & $8(16 \%)$ & $12(33 \%)$ \\
\hline Quintile 3 & $22(25 \%)$ & $13(25 \%)$ & $9(25 \%)$ \\
\hline Quintile 4 & $15(17 \%)$ & $13(25 \%)$ & $2(6 \%)$ \\
\hline Quintile 5 (most deprived) & $24(28 \%)$ & $14(28 \%)$ & $10(28 \%)$ \\
\hline \multicolumn{4}{|l|}{ Anthropometry } \\
\hline Height $(\mathrm{cm})$ & $172.6 \pm 8.6$ & $168.1 \pm 6.3$ & $178.9 \pm 7.3$ \\
\hline Weight (kg) & $112.6 \pm 20.1$ & $105.4 \pm 15.7$ & $122.9 \pm 21.3$ \\
\hline Waist circumference $(\mathrm{cm})$ & $106 \pm 12$ & $101 \pm 8$ & $113 \pm 12$ \\
\hline Waist-to-height ratio & $0.61 \pm 0.06$ & $0.60 \pm 0.04$ & $0.63 \pm 0.07$ \\
\hline Waist-to-hip ratio & $0.87 \pm 0.08$ & $0.82 \pm 0.04$ & $0.93 \pm 0.08$ \\
\hline BMI $\left(\mathrm{kg} / \mathrm{m}^{2}\right)$ & $36.9 \pm 5.3$ & $36.1 \pm 4.4$ & $37.9 \pm 6.4$ \\
\hline BMI SDS & $3.33 \pm 0.79$ & $3.17 \pm 0.63$ & $3.55 \pm 0.94$ \\
\hline Class I obesity & $29(33 \%)$ & $15(29 \%)$ & $14(39 \%)$ \\
\hline Class II obesity & $33(38 \%)$ & $23(45 \%)$ & $10(28 \%)$ \\
\hline Class III obesity & $25(29 \%)$ & $13(26 \%)$ & $12(33 \%)$ \\
\hline \multicolumn{4}{|l|}{ Body composition } \\
\hline Total body fat (\%) & $47.5 \pm 5.6$ & $50.0 \pm 4.8$ & $44.0 \pm 4.9$ \\
\hline \multicolumn{4}{|l|}{ Insulin sensitivity } \\
\hline HOMA-IR & $7.88 \pm 5.53$ & $7.21 \pm 5.66$ & $8.84 \pm 5.27$ \\
\hline Matsuda index & $1.73 \pm 1.13$ & $1.99 \pm 1.34$ & $1.38 \pm 0.63$ \\
\hline \multicolumn{4}{|l|}{ Maternal characteristics } \\
\hline Education (higher) $^{\mathrm{a}}$ & $55(70 \%)$ & $31(67 \%)$ & $24(75 \%)$ \\
\hline $\mathrm{BMI}\left(\mathrm{kg} / \mathrm{m}^{2}\right)$ & $33.7 \pm 7.8$ & $33.2 \pm 8.0$ & $34.4 \pm 7.5$ \\
\hline Class 1 obesity & $26(33 \%)$ & $14(30 \%)$ & $12(36 \%)$ \\
\hline Class 2 obesity & $11(14 \%)$ & $8(17 \%)$ & $3(9 \%)$ \\
\hline Class 3 obesity & $16(20 \%)$ & $7(15 \%)$ & $9(27 \%)$ \\
\hline \multicolumn{4}{|l|}{ Paternal characteristics } \\
\hline Education (higher) $^{\mathrm{a}}$ & $50(63 \%)$ & $26(55 \%)$ & $24(75 \%)$ \\
\hline $\operatorname{BMI}\left(\mathrm{kg} / \mathrm{m}^{2}\right)$ & $32.0 \pm 5.5$ & $31.4 \pm 5.2$ & $32.7 \pm 5.7$ \\
\hline Class 1 obesity & $19(27 \%)$ & $13(34 \%)$ & $6(18 \%)$ \\
\hline Class 2 obesity & $15(21 \%)$ & $5(13 \%)$ & $10(30 \%)$ \\
\hline Class 3 obesity & $6(9 \%)$ & $3(8 \%)$ & $3(9 \%)$ \\
\hline
\end{tabular}

Table 2. Demographic and clinical characteristics of participants enrolled into the Gut Bugs Trial. Age data are median [quartile 1, quartile 3]; other data are n (\%) or means $\pm \mathrm{SD}$, as appropriate. $B M I$ body mass index, HOMA-IR homeostatic model assessment of insulin resistance, $S D S$ standard deviation score. Obesity classes were defined as: Class I (BMI $\geq 30 \mathrm{~kg} / \mathrm{m}^{2}$ but $\left.<35 \mathrm{~kg} / \mathrm{m}^{2}\right)$; Class II $\left(B M I \geq 35 \mathrm{~kg} / \mathrm{m}^{2}\right.$ but $\left.<40 \mathrm{~kg} / \mathrm{m}^{2}\right)$; and Class

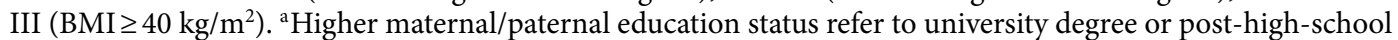
vocational qualification. ${ }^{b}$ Socioeconomic deprivation was estimated using the New Zealand Indices of Multiple Deprivation $^{73}$.

Reduction in insulin sensitivity as well as impaired glucose metabolism were common complications among our study population. Insulin resistance as assessed from the HOMA-IR values among our adolescents was more than 1.5 times higher when compared with adolescents with obesity in the $\mathrm{US}^{51}$ and Europe $\mathrm{e}^{52}$. In addition, more 


\begin{tabular}{|c|c|c|c|c|}
\hline Assessments & Cardiometabolic comorbidities ${ }^{\mathrm{a}}$ & All & Females & Males \\
\hline $\mathrm{N}$ & & 87 & 51 & 36 \\
\hline Anthropometry & Elevated waist circumference & $87(100 \%)$ & $51(100 \%)$ & $36(100 \%)$ \\
\hline \multirow{2}{*}{ Clinic blood pressure } & Pre-hypertension & $11(13 \%)$ & $4(8 \%)$ & $7(19 \%)$ \\
\hline & Hypertension & $7(8 \%)$ & $4(8 \%)$ & $3(8 \%)$ \\
\hline \multirow{8}{*}{$24 \mathrm{hABPM}$} & Awake pre-hypertension & $2(2 \%)$ & $1(2 \%)$ & $1(3 \%)$ \\
\hline & \begin{tabular}{|l|} 
Awake hypertension \\
\end{tabular} & $4(5 \%)$ & $3(6 \%)$ & $1(3 \%)$ \\
\hline & Asleep pre-hypertension & $16(18 \%)$ & $12(24 \%)$ & $4(11 \%)$ \\
\hline & Asleep hypertension & $9(10 \%)$ & $5(10 \%)$ & $4(11 \%)$ \\
\hline & Any time pre-hypertension & $15(17 \%)$ & $11(22 \%)$ & $4(11 \%)$ \\
\hline & Any time hypertension & $12(14 \%)$ & $7(14 \%)$ & $5(14 \%)$ \\
\hline & Non-dippers (systolic) & $43(49 \%)$ & $25(49 \%)$ & $18(50 \%)$ \\
\hline & Non-dippers (diastolic) ${ }^{b}$ & $18(21 \%)$ & $11(22 \%)$ & $7(19 \%)$ \\
\hline \multirow{6}{*}{ Glucose metabolism } & Elevated fasting glucose & $29(34 \%)$ & $12(24 \%)$ & $17(47 \%)$ \\
\hline & Elevated 2-h glucose (OGTT) & $10(12 \%)$ & $5(10 \%)$ & $5(14 \%)$ \\
\hline & Elevated HbAlc & $27(31 \%)$ & $1(2 \%)$ & $26(74 \%)$ \\
\hline & \begin{tabular}{|l|} 
Elevated fasting insulin \\
\end{tabular} & $80(94 \%)$ & $44(90 \%)$ & $36(100 \%)$ \\
\hline & Pre-diabetes & $44(52 \%)$ & $14(29 \%)$ & $30(83 \%)$ \\
\hline & Diabetes & $1(1 \%)$ & $1(2 \%)$ & $0(0 \%)$ \\
\hline \multirow{2}{*}{ Insulin resistance } & High HOMA-IR & $78(92 \%)$ & $42(86 \%)$ & $36(100 \%)$ \\
\hline & Low Matsuda index & $72(87 \%)$ & $37(79 \%)$ & $35(97 \%)$ \\
\hline \multirow{5}{*}{ Lipid profile } & High total cholesterol & $16(19 \%)$ & $10(20 \%)$ & $6(17 \%)$ \\
\hline & High LDL & $46(54 \%)$ & $28(56 \%)$ & $18(50 \%)$ \\
\hline & Low HDL & $37(43 \%)$ & $20(40 \%)$ & $17(47 \%)$ \\
\hline & High triglycerides & $17(20 \%)$ & $4(8 \%)$ & $13(36 \%)$ \\
\hline & Dyslipidaemia & $64(74 \%)$ & $37(74 \%)$ & $27(75 \%)$ \\
\hline \multirow{4}{*}{ Liver function } & Elevated ALT & $11(13 \%)$ & $6(12 \%)$ & $5(14 \%)$ \\
\hline & Elevated AST & $15(17 \%)$ & $10(20 \%)$ & $5(14 \%)$ \\
\hline & \begin{tabular}{|l|} 
Elevated GGT \\
\end{tabular} & $11(13 \%)$ & $6(12 \%)$ & $5(14 \%)$ \\
\hline & Abnormal liver function & $22(25 \%)$ & $14(28 \%)$ & $8(22 \%)$ \\
\hline \multirow{2}{*}{ Inflammatory markers } & Hyperuricaemia & $53(61 \%)$ & $34(67 \%)$ & $19(53 \%)$ \\
\hline & Elevated hsCRP & $24(28 \%)$ & $15(29 \%)$ & $9(25 \%)$ \\
\hline Metabolic health & Metabolic syndrome & $31(36 \%)$ & $13(26 \%)$ & $18(50 \%)$ \\
\hline
\end{tabular}

Table 3. Baseline cardiometabolic comorbidities of adolescents with obesity enrolled into the Gut Bugs Trial. Data are $\mathrm{n}(\%)$. ${ }^{\mathrm{a}}$ For the full definitions of all comorbidities please refer Table $1 .{ }^{\mathrm{b}}$ All diastolic non-dippers were also systolic non-dippers. 24hABPM 24-h ambulatory blood pressure monitoring, $A L T$ alanine transaminase, $A S T$ aspartate transaminase, $B P$ blood pressure, GGT gamma-glutamyl transferase, $H b A 1 c$ haemoglobin A1c, $H D L$ high-density lipoprotein cholesterol, HOMA-IR homeostatic model assessment of insulin resistance, $h s C R P$ high-sensitivity C-reactive protein, $L D L$ low-density lipoprotein cholesterol, OGTT oral glucosetolerance test.

than half of our participants had pre-diabetes (i.e. impaired fasting glycaemia, impaired glucose tolerance, and/or elevated glycated haemoglobin). It could be argued that our high rate of pre-diabetes could be attributed, at least in part, to our lower cut-off value for impaired fasting glycaemia (i.e. $\geq 5.6 \mathrm{mmol} / \mathrm{L}$ as recommended by the $\mathrm{ADA}^{53}$ and ISPAD ${ }^{54}$, rather than the WHO value $\geq 6.1 \mathrm{mmol} / \mathrm{L}^{55}$ ), as using the higher WHO cut-off, our pre-diabetes rate would have dropped from 52 to $38 \%$. Nonetheless, when compared to previous studies in US and Europe that used the same cut-off values as ours, the prevalence of pre-diabetes in our study was still 4 times greater ${ }^{52,56}$. Moreover, due to the high risk of diabetes in our vulnerable study population and our aim to prevent worsening of their metabolic health through early identification and intervention, we contend that the lower threshold for abnormal fasting glycaemia was justified. Nichols et al. reported that without appropriate intervention, nearly one in ten adults with pre-diabetes will develop T2DM within 3.5 years, and the progression to T2DM could be accelerated by risk factors such as increased BMI, elevated blood pressure and triglyceride levels, and lower HDL levels, all of which were present in our participant ${ }^{57}$. As improvement in insulin sensitivity and reversal of pre-diabetes have been reported with therapeutic interventions ${ }^{58}$, early identification of pre-diabetes among adolescents with obesity becomes increasingly important.

Although small, our study population was likely representative of Auckland's ethnic and socioeconomic make-up, with relatively similar demographics when compared to national census data ${ }^{59}$. Both ethnicity and socioeconomic status are factors known to be associated with an increased risk of obesity and obesity-related diseases $^{60}$. As we were able to recruit adolescents with obesity but not with any pre-diagnosed chronic conditions 


\begin{tabular}{|l|l|l|l|l|c|}
\hline Comorbidities $^{\mathbf{a}}$ & Classes I/II & Class III & p1 & Relative risk & p2 \\
\hline $\mathrm{N}$ & 62 & 25 & & & \\
\hline Pre-hypertension or hypertension & $11(18 \%)$ & $16(64 \%)$ & $<\mathbf{0 . 0 0 0 1}$ & $3.76(2.06,6.85)$ & $<\mathbf{0 . 0 0 0 1}$ \\
\hline Awake pre-hypertension or hypertension & $1(2 \%)$ & $5(20 \%)$ & $\mathbf{0 . 0 0 6 9}$ & $13.02(1.66,102.01)$ & $\mathbf{0 . 0 1 5}$ \\
\hline Sleep pre-hypertension or hypertension & $11(18 \%)$ & $14(56 \%)$ & $<\mathbf{0 . 0 0 1}$ & $3.30(1.76,6.18)$ & $<\mathbf{0 . 0 0 1}$ \\
\hline Systolic and diastolic non-dippers & $8(13 \%)$ & $10(40 \%)$ & $\mathbf{0 . 0 0 4 8}$ & $3.16(1.41,7.09)$ & $\mathbf{0 . 0 0 5 3}$ \\
\hline Pre-diabetes or diabetes & $30(48 \%)$ & $15(65 \%)$ & 0.17 & $1.19(0.83,1.70)$ & 0.35 \\
\hline Dyslipidaemia & $45(73 \%)$ & $19(79 \%)$ & 0.53 & $1.09(0.84,1.41)$ & 0.51 \\
\hline Abnormal liver function & $17(27 \%)$ & $5(20 \%)$ & 0.47 & $0.74(0.31,1.79)$ & 0.51 \\
\hline Hyperuricaemia & $34(55 \%)$ & $19(76 \%)$ & 0.067 & $1.42(1.03,1.95)$ & $\mathbf{0 . 0 3 1}$ \\
\hline Elevated hsCRP & $13(21 \%)$ & $11(44 \%)$ & $\mathbf{0 . 0 3 0}$ & $2.14(1.12,4.11)$ & $\mathbf{0 . 0 2 2}$ \\
\hline Metabolic syndrome & $17(27 \%)$ & $14(58 \%)$ & $\mathbf{0 . 0 0 7 4}$ & $1.99(1.19,3.34)$ & $\mathbf{0 . 0 0 9 1}$ \\
\hline
\end{tabular}

Table 4. Relative risks of comorbidities among participants according to their obesity class. Data are $\mathrm{n}(\%)$, or relative risks (adjusted for sex) and respective 95\% confidence intervals. P-values for statistically significant differences are shown in bold. Obesity classes were defined as: Class I (BMI $\geq 30$ but $\left.<35 \mathrm{~kg} / \mathrm{m}^{2}\right)$; Class II $(\geq 35$ but $\left.<40 \mathrm{~kg} / \mathrm{m}^{2}\right)$; and Class III $\left(\geq 40 \mathrm{~kg} / \mathrm{m}^{2}\right)$. All blood pressure parameters were derived from 24 -h ambulatory blood pressure monitoring. $h s C R P$ high-sensitivity $\mathrm{C}$-reactive protein. ${ }^{\text {a }}$ For the full definitions of comorbidities please refer to Table 1.

from the general population, our findings may be extrapolated to describe the health of adolescents with obesity in Auckland.

A strength of our study was our robust clinical assessments. In particular, accurate measurement of clinic BP is challenging, with wide variations due to many environmental factors ${ }^{61} .24 \mathrm{hABPM}$, is a far more robust method to identify BP abnormalities compared to commonly used clinic devices ${ }^{62}$. Notably, pre-hypertension/hypertension was underdiagnosed when measured using the clinic BP monitor; only one in five was diagnosed to have elevated BP whereas with a $24 \mathrm{hABPM}$, more than a third were reported to have elevated BP. Moreover, nearly a third of participants were diagnosed to have nocturnal prehypertension/hypertension which would have been undetected during daytime clinic BP measurements, and further emphasized the importance of undertaking BP monitoring over a 24 -h period. Participants also underwent an OGTT which provided a more comprehensive assessment of glucose homeostasis and insulin sensitivity ${ }^{53}$.

In conclusion, we identified a high prevalence of undiagnosed comorbidities among adolescents with obesity. Of note, the high prevalence of metabolic syndrome in our study population emphasises the importance of screening adolescents with obesity for these metabolic complications. Obesity is a complex chronic condition that once established is not only difficult to treat, but requires life-long support ${ }^{41}$. As a result, it is undeniable that prevention of obesity should be the primary focus in this health crisis. However, for adolescents with established obesity, early identification of individuals with poor metabolic health and implementation of early targeted interventions are important, with the aim of preventing the development of overt cardiometabolic disease.

\section{Data availability}

The clinical data cannot be made available in a public repository according to the strict conditions of the study's ethics approval. Nonetheless, anonymized and de-identified data could be made available to other investigators upon bona fide request, and following all the necessary approvals (including ethics) of the detailed study proposal and statistical analyses plan. Any queries should be directed to Prof Wayne Cutfield (w.cutfield@auckland.ac.nz).

Received: 13 July 2020; Accepted: 7 October 2020

Published online: 18 November 2020

\section{References}

1. NCD Risk Factor Collaboration. Worldwide trends in body-mass index, underweight, overweight, and obesity from 1975 to 2016 : A pooled analysis of 2416 population-based measurement studies in 128.9 million children, adolescents, and adults. Lancet 390 , 2627-2642, https://doi.org/10.1016/s0140-6736(17)32129-3 (2017).

2. World Health Organization. Obesity and Overweight-Key Facts. https://www.who.int/news-room/fact-sheets/detail/obesity-andoverweight (2020).

3. World Health Organization. Global Health Observatory (GHA) Data Repository-Overweight/Obesity. https://apps.who.int/gho/ data/node.main.A896 (2016)

4. New Zealand Ministry of Health. Tier 1 Statistics 2018/2019: New Zealand Health Survey, https://www.health.govt.nz/publicatio n/tier-1-statistics-2018-19-new-zealand-health-survey (2019).

5. Olds, T. S., Tomkinson, G. R., Ferrar, K. E. \& Maher, C. A. Trends in the prevalence of childhood overweight and obesity in Australia between 1985 and 2008. Int. J. Obes. (London) 34, 57-66. https://doi.org/10.1038/ijo.2009.211 (2010).

6. Pearson, S., Hansen, B., Sørensen, T. I. \& Baker, J. L. Overweight and obesity trends in Copenhagen schoolchildren from 2002 to 2007. Acta Paediatr. 99, 1675-1678. https://doi.org/10.1111/j.1651-2227.2010.01897.x (2010).

7. Zhang, J. et al. Trends in the prevalence of overweight and obesity among Chinese school-age children and adolescents from 2010 to 2015. Child Obes. 14, 182-188. https://doi.org/10.1089/chi.2017.0309 (2018).

8. Skinner, A. C., Ravanbakht, S. N., Skelton, J. A., Perrin, E. M. \& Armstrong, S. C. Prevalence of obesity and severe obesity in US children, 1999-2016. Pediatrics 141, https://doi.org/10.1542/peds.2017-3459 (2018). 
9. Rokholm, B., Baker, J. L. \& Sørensen, T. I. A. The levelling off of the obesity epidemic since the year 1999-A review of evidence and perspectives. Obes. Rev. 11, 835-846. https://doi.org/10.1111/j.1467-789X.2010.00810.x (2010).

10. New Zealand Ministry of Health. Obesity Statistics. https://www.health.govt.nz/nz-health-statistics/health-statistics-and-data-sets/ obesity-statistics (2019).

11. Utter, J., Denny, S., Teevale, T., Peiris-John, R. \& Dyson, B. Prevalence and recent trends in overweight, obesity, and severe obesity among New Zealand adolescents. Child Obes. 11, 585-589. https://doi.org/10.1089/chi.2014.0151 (2015).

12. Patton, G. C. \& Viner, R. Pubertal transitions in health. Lancet 369, 1130-1139. https://doi.org/10.1016/s0140-6736(07)60366-3 (2007).

13. Jasik, C. B. \& Lustig, R. H. Adolescent obesity and puberty: The "perfect storm". Ann. N. Y. Acad. Sci. 1135, 265-279 (2008).

14. Kelsey, M. M. \& Zeitler, P. S. Insulin resistance of puberty. Curr. Diab. Rep. 16, 64. https://doi.org/10.1007/s11892-016-0751-5 (2016).

15. Gordon-Larsen, P., The, N. S. \& Adair, L. S. Longitudinal trends in obesity in the United States from adolescence to the third decade of life. Obesity (Silver Spring) 18, 1801-1804. https://doi.org/10.1038/oby.2009.451 (2010).

16. Zimmet, P. et al. The metabolic syndrome in children and adolescents-An IDF consensus report. Pediatr. Diabetes 8, 299-306. https://doi.org/10.1111/j.1399-5448.2007.00271.x (2007).

17. Carnethon, M. R. et al. Risk factors for the metabolic syndrome: The Coronary Artery Risk Development in Young Adults (CARDIA) study, 1985-2001. Diabetes Care 27, 2707-2715. https://doi.org/10.2337/diacare.27.11.2707 (2004).

18. Tailor, A. M., Peeters, P. H., Norat, T., Vineis, P. \& Romaguera, D. An update on the prevalence of the metabolic syndrome in children and adolescents. Int. J. Pediatr. Obes. 5, 202-213. https://doi.org/10.3109/17477160903281079 (2010).

19. Mayer-Davis, E. J. et al. Incidence trends of type 1 and type 2 diabetes among youths, 2002-2012. N. Engl. J. Med. 376, 1419-1429. https://doi.org/10.1056/NEJMoa1610187 (2017).

20. Isomaa, B. et al. Cardiovascular morbidity and mortality associated with the metabolic syndrome. Diabetes Care 24, 683-689. https://doi.org/10.2337/diacare.24.4.683 (2001).

21. Engin, A. The definition and prevalence of obesity and metabolic syndrome. Adv. Exp. Med. Biol. 960, 1-17. https://doi. org/10.1007/978-3-319-48382-5_1 (2017).

22. Demmer, R. T., Zuk, A. M., Rosenbaum, M. \& Desvarieux, M. Prevalence of diagnosed and undiagnosed type 2 diabetes mellitus among US adolescents: Results from the continuous NHANES, 1999-2010. Am. J. Epidemiol. 178, 1106-1113. https://doi. org/10.1093/aje/kwt088 (2013).

23. Sjardin, N. et al. Increasing incidence of type 2 diabetes in New Zealand children $<15$ years of age in a regional-based diabetes service, Auckland, New Zealand. J. Paediatr. Child Health 54, 1005-1010. https://doi.org/10.1111/jpc.13924 (2018).

24. Lindberg, L., Danielsson, P., Persson, M., Marcus, C. \& Hagman, E. Association of childhood obesity with risk of early all-cause and cause-specific mortality: A Swedish prospective cohort study. PLoS Med. 17, e1003078. https://doi.org/10.1371/journal.pmed.10030 78 (2020).

25. Zabarsky, G. et al. Impact of severe obesity on cardiovascular risk factors in youth. J. Pediatr. 192, 105-114. https://doi.org/10.1016/j. jpeds.2017.09.066 (2018)

26. Daniels, S. R. Complications of obesity in children and adolescents. Int. J. Obes. (Lond.) 33(Suppl 1), S60-65. https://doi.org/10.1038/ ijo.2009.20 (2009).

27. van Geel, M., Vedder, P. \& Tanilon, J. Are overweight and obese youths more often bullied by their peers? A meta-analysis on the correlation between weight status and bullying. Int. J. Obes. (Lond.) 38, 1263-1267, https://doi.org/10.1038/ijo.2014.117 (2014).

28. Gortmaker, S. L., Must, A., Perrin, J. M., Sobol, A. M. \& Dietz, W. H. Social and economic consequences of overweight in adolescence and young adulthood. N. Engl. J. Med. 329, 1008-1012. https://doi.org/10.1056/nejm199309303291406 (1993).

29. Quek, Y. H., Tam, W. W. S., Zhang, M. W. B. \& Ho, R. C. M. Exploring the association between childhood and adolescent obesity and depression: A meta-analysis. Obes. Rev. 18, 742-754. https://doi.org/10.1111/obr.12535 (2017).

30. Anderson, Y. C. et al. Prevalence of comorbidities in obese New Zealand children and adolescents at enrolment in a Communitybased obesity programme. J. Paediatr. Child Health 52, 1099-1105 (2016).

31. Grant, A. M. et al. Body mass index status is effective in identifying metabolic syndrome components and insulin resistance in Pacific Island teenagers living in New Zealand. Metabolism 57, 511-516. https://doi.org/10.1016/j.metabol.2007.11.013 (2008).

32. Leong, K. S. W. et al. Protocol for the Gut Bugs Trial: A randomised double-blind placebo-controlled trial of gut microbiome transfer for the treatment of obesity in adolescents. BMJ Open 9, e026174. https://doi.org/10.1136/bmjopen-2018-026174 (2019).

33. World Medical Association. World Medical Association Declaration of Helsinki: Ethical principles for medical research involving human subjects. JAMA 310, 2191-2194. https://doi.org/10.1001/jama.2013.281053 (2013).

34. de Onis, M. et al. Development of a WHO growth reference for school-aged children and adolescents. Bull. World Health Organ. 85, 660-667, https://doi.org/10.2471/blt.07.043497 (2007).

35. World Health Organization. Body Mass Index-BMI. https://www.euro.who.int/en/health-topics/disease-prevention/nutrition/ahealthy-lifestyle/body-mass-index-bmi (2006).

36. Wallace, T. M., Levy, J. C. \& Matthews, D. R. Use and abuse of HOMA modeling. Diabetes Care 27, 1487-1495. https://doi. org/10.2337/diacare.27.6.1487 (2004).

37. Matsuda, M. \& DeFronzo, R. Insulin sensitivity indices obtained from oral glucose tolerance testing: Comparison with the euglycemic insulin clamp. Diabetes Care 22, 1462-1470. https://doi.org/10.2337/diacare.22.9.1462 (1999).

38. Spiegelman, D. \& Hertzmark, E. Easy SAS calculations for risk or prevalence ratios and differences. Am. J. Epidemiol. 162, 199-200. https://doi.org/10.1093/aje/kwi188 (2005).

39. Keskin, M., Kurtoglu, S., Kendirci, M., Atabek, M. E. \& Yazici, C. Homeostasis model assessment is more reliable than the fasting glucose/insulin ratio and quantitative insulin sensitivity check index for assessing insulin resistance among obese children and adolescents. Pediatrics 115, e500-e503. https://doi.org/10.1542/peds.2004-1921 (2005).

40. Kernan, W. N. et al. Pioglitazone improves insulin sensitivity among nondiabetic patients with a recent transient ischemic attack or ischemic stroke. Stroke 34, 1431-1436. https://doi.org/10.1161/01.Str.0000071108.00234.0e (2003).

41. Lakshman, R., Elks, C. E. \& Ong, K. K. Childhood obesity. Circulation 126, 1770-1779. https://doi.org/10.1161/circulatio naha.111.047738 (2012).

42. Friend, A., Craig, L. \& Turner, S. The prevalence of metabolic syndrome in children: A systematic review of the literature. Metab. Syndr. Relat. Disord. 11, 71-80. https://doi.org/10.1089/met.2012.0122 (2013).

43. Eyzaguirre, F. et al. Prevalence of metabolic syndrome in children and adolescents who consult with obesity. Rev. Med. Chil. 139, 732-738. https://doi.org/10.4067/S0034-98872011000600006 (2011).

44. Galera-Martínez, R. et al. Prevalence of metabolic syndrome among adolescents in a city in the Mediterranean area: Comparison of two definitions. Nutr. Hosp. 32, 627-633. https://doi.org/10.3305/nh.2015.32.2.9278 (2015).

45. Guijarro de Armas, M. A., Monereo Megías, S., Merino Viveros, M., Iglesias Bolaños, P. \& Vega Piñero, B. Prevalence of metabolic syndrome in a population of obese children and adolescents. Endocrinol. Nutr. 59, 155-159, https://doi.org/10.1016/j.endon u.2012.01.003 (2012)

46. Romero-Velarde, E. et al. Prevalence of metabolic syndrome and associated factors in children and adolescents with obesity. Rev. Med. Inst. Mex. Seguro Soc. 54, 568-575 (2016). 
47. Šimunović, M., Božić, J., Milić, L., Unić, I. \& Škrabić, V. The prevalence of metabolic syndrome and cardiovascular risk factors in obese children and adolescents in dalmatia: A hospital based study. Int. J. Endocrinol. 2016, 1823561. https://doi. org/10.1155/2016/1823561 (2016).

48. Calcaterra, V. et al. Prevalence of metabolic syndrome (MS) in children and adolescents with varying degrees of obesity. Clin. Endocrinol. (Oxf.) 68, 868-872. https://doi.org/10.1111/j.1365-2265.2007.03115.x (2008).

49. Gobato, A. O., Vasques, A. C., Zambon, M. P., Barros Filho Ade, A. \& Hessel, G. Metabolic syndrome and insulin resistance in obese adolescents. Rev. Paul Pediatr. 32, 55-62, https://doi.org/10.1590/s0103-05822014000100010 (2014).

50. Weiss, R. et al. Obesity and the metabolic syndrome in children and adolescents. N. Engl. J. Med. 350, 2362-2374. https://doi. org/10.1056/NEJMoa031049 (2004).

51. Lee, J. M., Okumura, M. J., Davis, M. M., Herman, W. H. \& Gurney, J. G. Prevalence and determinants of insulin resistance among U.S. adolescents: a population-based study. Diabetes Care 29, 2427-2432, https://doi.org/10.2337/dc06-0709 (2006).

52. Koutny, F. et al. Prevalence of prediabetes and type 2 diabetes in children with obesity and increased transaminases in European German-speaking countries. Analysis of the APV initiative. Pediatr. Obes. 15, e12601, https://doi.org/10.1111/ijpo.12601 (2020).

53. American Diabetes Association. Classification and diagnosis of diabetes: Standards of medical care in diabetes 2018. Diabetes Care 41, S13-S27. https://doi.org/10.2337/dc18-S002 (2018).

54. Mayer-Davis, E. J. et al. ISPAD Clinical Practice Consensus Guidelines 2018: Definition, epidemiology, and classification of diabetes in children and adolescents. Pediatr. Diabetes 19(Suppl 27), 7-19. https://doi.org/10.1111/pedi.12773 (2018).

55. World Health Organization. Definition and diagnosis of diabetes mellitus and intermediate hyperglycaemia: Report of a WHO/ IDF consultation. in Report No. 9241594934 (Geneva, Switzerland, 2006).

56. Lee, A. M., Fermin, C. R., Filipp, S. L., Gurka, M. J. \& DeBoer, M. D. Examining trends in prediabetes and its relationship with the metabolic syndrome in US adolescents, 1999-2014. Acta Diabetol. 54, 373-381. https://doi.org/10.1007/s00592-016-0958-6 (2017).

57. Nichols, G. A., Hillier, T. A. \& Brown, J. B. Progression from newly acquired impaired fasting glucose to type 2 diabetes. Diabetes Care 30, 228-233. https://doi.org/10.2337/dc06-1392 (2007).

58. Garnett, S. P. et al. Improved insulin sensitivity and body composition, irrespective of macronutrient intake, after a 12 month intervention in adolescents with pre-diabetes; RESIST a randomised control trial. BMC Pediatr. 14, 289. https://doi.org/10.1186/ s12887-014-0289-0 (2014).

59. Stats NZ. 2013 Census Tables About a Place. https://archive.stats.govt.nz/Census/2013-census/data-tables/tables-about-a-place .aspx (2013).

60. Woo Baidal, J. A. et al. Risk factors for childhood obesity in the first 1,000 days: A systematic review. Am. J. Prev. Med. 50, 761-779, https://doi.org/10.1016/j.amepre.2015.11.012 (2016).

61. O’Brien, E., Waeber, B., Parati, G., Staessen, J. \& Myers, M. G. Blood pressure measuring devices: Recommendations of the European Society of Hypertension. BMJ 322, 531-536. https://doi.org/10.1136/bmj.322.7285.531 (2001).

62. Lurbe, E. et al. 2016 European Society of Hypertension guidelines for the management of high blood pressure in children and adolescents. J. Hypertens. 34, 1887-1920. https://doi.org/10.1097/HJH.0000000000001039 (2016).

63. Eisenmann, J. C. Waist circumference percentiles for 7- to 15-year-old Australian children. Acta Paediatr. 94, 1182-1185. https:// doi.org/10.1111/j.1651-2227.2005.tb02071.x (2005).

64. Frithioff-Bøjsøe, C. et al. Glucose metabolism in children and adolescents: Population-based reference values and comparisons to children and adolescents enrolled in obesity treatment. Pediatr. Diabetes 20, 538-548. https://doi.org/10.1111/pedi.12859 (2019).

65. NCEP Expert Panel. Executive summary of the third report of the National Cholesterol Education Program (NCEP) expert panel on detection, evaluation, and treatment of high blood cholesterol in adults (Adult Treatment Panel III). JAMA 285, 2486-2497, https://doi.org/10.1001/jama.285.19.2486 (2001).

66. European Atherosclerosis Society. Strategies for the prevention of coronary heart disease: A policy statement of the European Atherosclerosis Society. Eur. Heart J. 8, 77-88. https://doi.org/10.1093/oxfordjournals.eurhearti.a062165 (1987).

67. Thefeld, W., Hoffmeister, H., Busch, E.-W., Koller, P. \& Vollmar, J. Normal values of serum uric acid depending on age and sex with one new enzymatic uric acid color test. Dtsch. Med. Woschenschr. 98, 380-384. https://doi.org/10.1055/s-0028-1106819 (1973).

68. Schlebusch, H., Liappis, N., Kalina, E. \& Klein, C. High sensitive CRP and creatinine: reference intervals from infancy to childhood. J. Lab. Med. 26, 341-346. https://doi.org/10.1046/j.1439-0477.2002.02071.x (2002).

69. Dati, F. et al. Consensus of a group of professional societies and diagnostic companies on guidelines for interim reference ranges for 14 proteins in serum based on the standardization against the IFCC/BCR/CAP reference material (CRM 470). Eur. J. Clin. Chem. Clin. Biochem. 34, 517-520 (1996).

70. Klein, G., Lehmann, P., Michel, E. \& Regenauer, H. Comparison of the IFCC methods for ALT, AST and GGT at $37^{\circ} \mathrm{C}$ with the established standard methods at $25^{\circ} \mathrm{C}$ and $37^{\circ} \mathrm{C}$. Lab. Med. 18, 403-404 (1994).

71. Thefeld, W., Hoffmeister, H., Busch, E.-W., Koller, P. \& Vollmar, J. Reference values for the determinations of the transaminases GOT and GPT as well as serum alkaline phosphatase using optimized standard methods. Dtsch. Med. Wochenschr. 99, 343-351. https://doi.org/10.1055/s-0028-1107760 (1974).

72. Thomas, L. et al. Consensus of DGKL and VDGH for interim reference intervals on enzymes in serum. J. Lab. Med. 29, 301-308. https://doi.org/10.1515/JLM.2005.041 (2005).

73. Exeter, D., Browne, M. M., Crengle, S., Lee, A. \& Zhao, J. New Zealand indices of multiple deprivation (IMD). PLoS ONE 12, e0181260. https://doi.org/10.1371/journal.pone.0181260 (2016).

\section{Author contributions}

W.S.C. and J.O.S. supervised all aspects of the research study. W.S.C. and J.O.S. led the Gut Bugs Trial conception and design. All authors contributed to the Gut Bugs Trial conception and design. K.S.W.L. and J.G.B.D. compiled the data, which were analysed by K.S.W.L. and J.G.B.D. All authors contributed to the interpretation of the results. K.S.W.L., J.G.B.D., and W.S.C. wrote the manuscript with critical input from all other authors. W.S.C. and J.O.S. had full access to all the data in the trial and had final responsibility for the decision to submit the trial for publication. All authors have approved the final version of this manuscript and have agreed to be accountable for all aspects of this work.

\section{Funding}

This study was funded by the Rockfield Trust and A Better Start-National Science Challenge. V Chiavaroli was supported (in part) by a European Society for Paediatric Endocrinology (ESPE) Research Fellowship, sponsored by Novo Nordisk A/S; TN Jayasinghe received a University of Auckland Scholarship; and BB Albert was supported by Rutherford and Maurice Paykel Research Fellowships. 


\section{Competing interests}

The authors declare no competing interests.

\section{Additional information}

Correspondence and requests for materials should be addressed to J.M.O. or W.S.C.

Reprints and permissions information is available at www.nature.com/reprints.

Publisher's note Springer Nature remains neutral with regard to jurisdictional claims in published maps and institutional affiliations.

(c) (1) Open Access This article is licensed under a Creative Commons Attribution 4.0 International License, which permits use, sharing, adaptation, distribution and reproduction in any medium or format, as long as you give appropriate credit to the original author(s) and the source, provide a link to the Creative Commons licence, and indicate if changes were made. The images or other third party material in this article are included in the article's Creative Commons licence, unless indicated otherwise in a credit line to the material. If material is not included in the article's Creative Commons licence and your intended use is not permitted by statutory regulation or exceeds the permitted use, you will need to obtain permission directly from the copyright holder. To view a copy of this licence, visit http://creativecommons.org/licenses/by/4.0/.

(c) The Author(s) 2020 